\title{
Effects of curcumin complexes on MDA-MB-231 breast cancer cell proliferation
}

\author{
FATIMA MOHAMMED ${ }^{1}$, FIZA RASHID-DOUBELL ${ }^{1}$, SAFA TAHA $^{2}$, SEAMAS CASSIDY $^{1}$ and SALIM FREDERICKS $^{1}$ \\ ${ }^{1}$ Department of Basic Medical Sciences, Royal College of Surgeons in Ireland, Medical University of Bahrain, \\ Busaiteen 228; ${ }^{2}$ Department of Molecular Medicine, College of Medicine and Medical Sciences, \\ Princess Al-Jawhara Centre for Molecular Medicine, Arabian Gulf University, Manama 2827, Kingdom of Bahrain
}

Received October 19, 2019; Accepted March 24, 2020

DOI: $10.3892 /$ ijo.2020.5065

\begin{abstract}
Curcumin displays anticancer properties; however, some issues with the drug delivery mode limit its therapeutic use. Although reformulation and derivatization of curcumin have improved its bioavailability, curcumin derivatives may not retain the same anticancer properties as the parent compound. The present study investigated the anticancer properties of two curcumin complexes, the iron-curcumin $\left[\mathrm{Fe}(\mathrm{Cur})_{3}\right]$ and boron-curcumin $\left[\mathrm{B}(\mathrm{Cur})_{2}\right]$ complexes, in the MDA-MB-231 breast cancer cell line. The cellular localization of curcumin, $\mathrm{B}(\mathrm{Cur})_{2}$ and $\mathrm{Fe}(\mathrm{Cur})_{3}$ was determined by fluorescence microscopy. Cell proliferation, migration and invasion were also analysed. Furthermore, apoptosis-associated proteins were detected by using a proteome profiler array, and ion channel gene expression was analysed by reverse transcription-quantitative PCR. The results demonstrated that the three compounds were localized in the perinuclear and cytoplasmic regions of the cell, and displayed cytotoxicity with $\mathrm{IC}_{50}$ values of 25,35 and $8 \mu \mathrm{M}$ for curcumin, $\mathrm{B}(\mathrm{Cur})_{2}$ and $\mathrm{Fe}(\mathrm{Cur})_{3}$, respectively. In addition, the three compounds inhibited cell invasion, whereas only curcumin and $\mathrm{B}(\mathrm{Cur})_{2}$ inhibited cell migration. Furthermore, cell exposure to curcumin resulted in an increase in the relative expression of the two key proapoptotic proteins, cytochrome c and cleaved caspase-3, as well as the antiapoptotic protein haem oxygenase-1. In addition, curcumin increased the expression levels of the voltage-gated potassium channels Kv2.1 and Kv3.2. Similarly, the expression levels of the chloride channel bestrophin-1 and the calcium channel coding gene calcium voltage-gated channel auxiliary subunit $\gamma 4$ were increased following exposure to curcumin. Taken together, these results indicated that $\mathrm{Fe}(\mathrm{Cur})_{3}$ and $\mathrm{B}(\mathrm{Cur})_{2}$ may
\end{abstract}

Correspondence to: Dr Salim Fredericks, Department of Basic Medical Sciences, Royal College of Surgeons in Ireland, Medical University of Bahrain, P.O. Box 15503, Adliya Post Office, Road 3601, Manama 2827, Kingdom of Bahrain

E-mail: sfredericks@rcsi-mub.com

Key words: breast cancer, curcumin, potassium channels, haem oxygenase-1 display similar anticancer properties as curcumin, suggesting that chemical complexation may be considered as a strategy for improving the potency of curcumin in the treatment of breast cancer.

\section{Introduction}

Cancer was responsible for 9.6 million deaths in 2018 worldwide, according to the World Health Organization Global Cancer Observatory (1). Breast cancer is the most common cancer in women with 2.1 million newly diagnosed cases worldwide in 2018 (1). Breast cancer is a heterogeneous disease with several subtypes that are classified based upon a variety of clinical and histopathological features (2-4). The lack of expression of oestrogen receptor (ER) and progesterone receptor (PR) and the absence of human epidermal growth factor Receptor-2 (HER2) overexpression assessed by immunohistochemistry defines the triple-negative breast cancer (TNBC) subtype. Poor long-term outcomes are associated with TNBC compared with other breast cancer subtypes (5-8). Mammography screening accounted for a decrease in breast cancer mortality in the recent years $(9,10)$. However, despite the numerous therapeutic options, including chemotherapy, hormonal therapy and radiotherapy, about $30 \%$ of patients who are treated at early-stages relapse (11). In most cases, treatment is effective at first, but resistance to therapy and disease progression eventually occur. Because treatment resistance has become common (11), it is crucial to provide novel treatment strategies. Alternative treatments may emerge from the development of either novel/unconventional therapeutic compounds or novel pharmacological approaches. The natural phytochemical compound curcumin exerts some effects on several biochemical pathways and drug targets. At present, curcumin is being widely investigated for its potential therapeutic use in various diseases, including Alzheimer's disease, cystic fibrosis and several types of cancer (12-19).

Curcumin has been reported to display antioxidant, anti-inflammatory, antiproliferative, proapoptotic and anticancer properties (20). The antioxidant effects of curcumin have been used in the treatment of pancreatitis (21), spinal cord injury (22) and complications associated with diabetes (23). The anti-inflammatory effects of curcumin have been demonstrated 
in diabetes (23) and in the treatment of cancer therapy-induced oral mucositis (24). Curcumin also displays anticancer properties that are applicable to the clinic (25-27). The clinical use of curcumin has been limited by its low aqueous solubility and stability, resulting in low oral bioavailability $(28,29)$. Structural modification and encapsulation of curcumin have been used to improve its pharmacokinetic profile (30). Furthermore, reformulations of curcumin have been investigated in order to improve its delivery directly to the tumour mass within the breast tissue (31-33). Improved curcumin stability has been achieved by structural modifications, including replacement of the $\beta$-diketone moiety with metal ions $(34,35)$; however, the effects of these modifications on the cytotoxic properties of curcumin have not yet been investigated. In addition, whether these novel complexes can enter the cell and localize in a similar manner to curcumin remain unknown. A suitable breast cancer cell line may be employed to investigate the localization and movement of curcumin-derived compounds into cells. The MDA-MB-231 cell line (36) is an aggressive and invasive breast cancer cell line, which lacks ER, PR and HER2 expression. This cell line is therefore referred to as a triple-negative breast cancer cell line (37). The absence of ER expression results in MDA-MB-231 cell insensitivity to antihormone-based therapies, including tamoxifen (38). Clinically, triple-negative breast cancer has limited treatment options. The MDA-MB-231 cell line is thus commonly used to investigate the molecular basis of this type of breast cancer and for the development of novel therapeutic approaches.

Resistance to apoptosis is a key characteristic of cancer cells (39). Curcumin has been reported to inhibit proliferation by inducing apoptosis in MDA-MB-231 breast cancer cells via increasing the $\mathrm{Bax} / \mathrm{Bcl}-2$ ratio or upregulating p21 expression $(40,41)$. It was also reported that curcumin can decrease MDA-MB-231 cell migration and invasion without affecting apoptosis (42). However, the anticancer activity of curcumin in relation to apoptosis, and the expression of proapoptotic and antiapoptotic proteins have not been fully described.

Ion channels directly or indirectly influence most basic cellular processes. Subsequently, ion channels also affect most malignant processes in cancer cells, including sustained proliferation (43-45), tissue invasion (43), metastasis $(46,47)$ and programmed cell death $(48,49)$. A previous study demonstrated that molecular, biological and pharmacological inhibition of voltage-gated potassium channels $(\mathrm{K} v)$ reduces cancer cell proliferation, whereas overexpression of certain $\mathrm{K} v$ channels can stimulate cell proliferation (50). Furthermore, when cells receive a death stimuli, they decreases in size during a process called apoptotic volume decrease (AVD). AVD occurs before the cascade of biochemical events that induces apoptosis (51) and is primarily induced by potassium efflux across the plasma membrane. Numerous potassium channels are essential for controlling and regulating the flow of potassium into and out of the cell. Because of the pivotal role of potassium channels during AVD, cancer cells may evade apoptosis by downregulating potassium channel expression. For example, $\mathrm{K} v 1.3$ and $\mathrm{K} v 1.5$ are expressed at reduced levels in many types of human cancer cells compared with normal cells (52). Other potassium channels, including voltage-gated potassium channels $\mathrm{K} v 1.1, \mathrm{~K} v 1.3, \mathrm{~K} v 1.5, \mathrm{~K} v 2.1$ and $\mathrm{K} v 11.1$, serve crucial roles during apoptosis (53). In addition to AVD associated with a decrease in cytoplasmic potassium concentration, this potassium movement promotes various cellular events that are critical for programmed cell death. These events include mitochondrial depolarization and cytochrome c release from mitochondria as well as cleavage of procaspase 3 and enhanced endonuclease activity (53). Furthermore, Bax is known to inhibit mitochondrial potassium channels downstream of pro-apoptotic signals. The activation of the mitochondrial pathway of apoptosis by the pro-apoptotic protein Bax is mediated via the direct inhibition of mitochondrial Kv1.3 channels by BAX in the outer mitochondrial membrane (54). It has been reported that curcumin displays inhibitory effects on potassium channels, mediating the curcumin-induced anticancer and anti-inflammatory properties in monocytic leukaemia and effector memory $\mathrm{T}$ cells $(55,56)$. In addition, curcumin decreases potassium channel currents by inactivating the gating of $\mathrm{K} v 2.1$ in 293 cells (57).

It has been demonstrated that the solubility and stability of curcumin can be increased by complexation with boron and iron (34). The aim of this study was to assess the anti-cancer properties of these curcumin complexes. The present study examined the effects of soluble structurally modified curcumin-based compounds on the MDA-MB-231 cell line. Furthermore, the inhibitory effects of curcumin, boron-curcumin $\left[\mathrm{B}(\mathrm{Cur})_{2}\right.$ ] and iron-curcumin $\left[\mathrm{Fe}(\mathrm{Cur})_{3}\right]$ on MDA-MB-231 cell proliferation, migration and invasion were investigated. In addition, the effect of the curcumin compounds on the apoptosis-proteome and gene expression of certain ion-channels was assessed.

\section{Materials and methods}

Cell lines. The oestrogen negative MDA-MB-231 cell line was obtained from the American Type Culture Collection. Cells were cultured in DMEM (Gibco; Thermo Fisher Scientific, Inc.; cat. no. 12491015) supplemented with 5\% fetal bovine serum (FBS; Sigma-Aldrich; Merck KGaA; cat. no. F2442), $100 \mathrm{U} / \mathrm{ml}$ penicillin, $100 \mu \mathrm{g} / \mathrm{ml}$ streptomycin (Gibco; Thermo Fisher Scientific, Inc.; cat. no. 15070063), $600 \mu \mathrm{g} / \mathrm{ml}$ L-glutamine (Sigma-Aldrich; Merck KGaA; cat. no. G7513) and 6/500 $\mathrm{ml} 100 \mathrm{X}$ non-essential amino acids (Gibco; Thermo Fisher Scientific, Inc.; cat. no. 11140050) and placed at $37^{\circ} \mathrm{C}$ in a humidified incubator containing $5 \% \mathrm{CO}_{2}$.

Drugs and reagents. Curcumin was purchased from Sigma-Aldrich: Merck KGaA (cat. no. C7727). B(Cur) and $\mathrm{Fe}(\mathrm{Cur})_{3}$ were synthesized as previously described by Khalil et al (58). The improved photostability of $\mathrm{B}(\mathrm{Cur})_{2}$ and $\mathrm{Fe}(\mathrm{Cur})_{3}$ relative to curcumin has been previously validated (34). Curcumin, $\mathrm{B}(\mathrm{Cur})_{2}$ and $\mathrm{Fe}(\mathrm{Cur})_{3}$ were initially dissolved in DMSO into a $10 \mathrm{mM}$ stock solution that was stored at $-20^{\circ} \mathrm{C}$. Stock solutions were later diluted in DMEM to the desired final concentrations. The structures of curcumin, $\mathrm{B}(\mathrm{Cur})_{2}$ and $\mathrm{Fe}(\mathrm{Cur})_{3}$ are presented in Fig. 1.

Fluorescence microscopy. MDA-MB-231 cells $\left(350 \times 10^{3} \mathrm{cell} / \mathrm{ml}\right)$ were seeded in 8-chamber slides (Eppendorf; cat no. 30742036) and incubated for $24 \mathrm{~h}$ at $37^{\circ} \mathrm{C}$ with $5 \%$ $\mathrm{CO}_{2}$. Subsequently, cells were treated with curcumin $(25 \mu \mathrm{M})$, $\mathrm{B}(\mathrm{Cur})_{2}(30 \mu \mathrm{M})$ and $\mathrm{Fe}(\mathrm{Cur})_{3}(8 \mu \mathrm{M})$ or vehicle (control group) for 5 min and immediately fixed with $3.7 \%$ formaldehyde at 


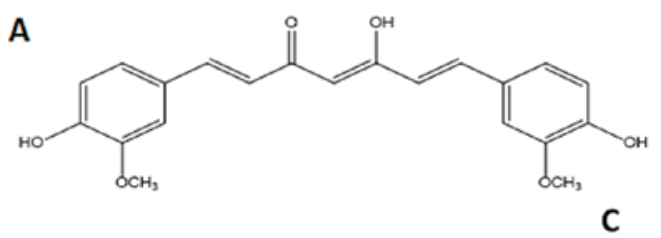

B
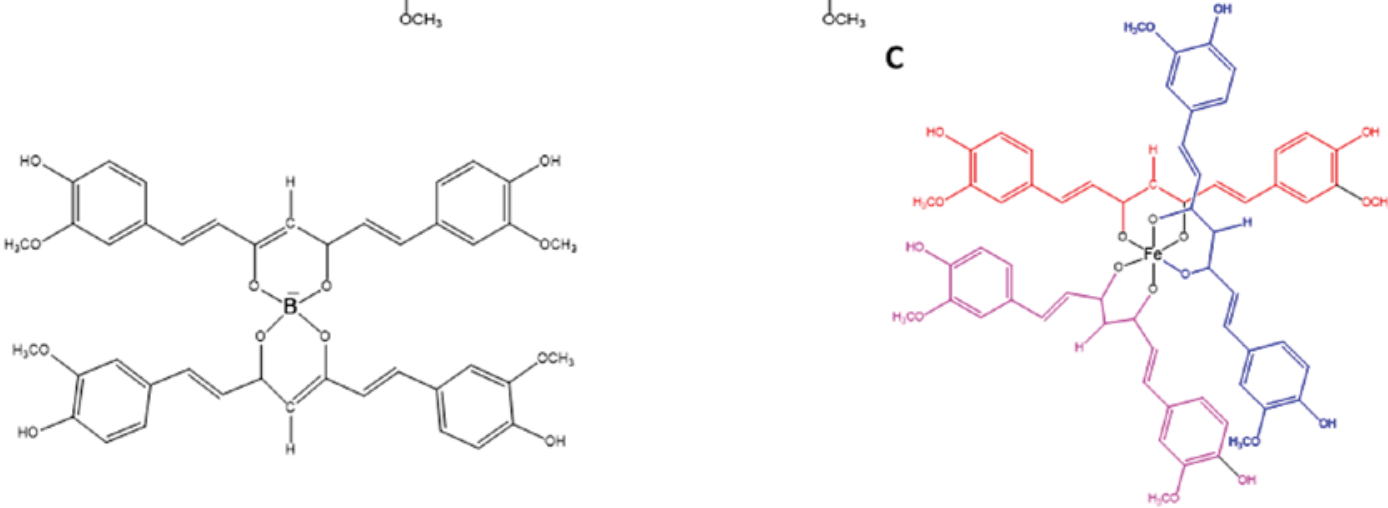

Figure 1. Chemical structures of (A) curcumin, (B) boron-curcumin and (C) iron-curcumin.

room temperature for $10 \mathrm{~min}$. Cells were counterstained with DAPI at room temperature for $5 \mathrm{~min}$ to visualize the nucleus. Stained cells were observed using a BX43 fluorescence microscope (Olympus Corporation; magnification, x100) to determine the cellular localization of curcumin and its metal derivatives. Images were analysed using CellSens Standard software (version 1.9; Olympus Corporation).

Sulforhodamine B (SRB) assay. The in vitro effect of curcumin, $\mathrm{B}(\mathrm{Cur})_{2}$ and $\mathrm{Fe}(\mathrm{Cur})_{3}$ on breast cancer cell proliferation was evaluated by using the SRB assay as previously described by Skehan et al (59). Briefly, MDA-MB-231 cells were seeded in triplicate at the density of $1 \times 10^{4}$ cells/well into a 96-well plate and incubated overnight at $37^{\circ} \mathrm{C}$ with $5 \% \mathrm{CO}_{2}$. Cells were treated with vehicle or various concentrations $(5,10,20$, $30,40,50$ and $100 \mu \mathrm{M})$ of curcumin, $\mathrm{B}(\mathrm{Cur})_{2}$ and $\mathrm{Fe}(\mathrm{Cur})_{3}$ for $48 \mathrm{~h}$. Subsequently, cells were fixed overnight with cold $10 \%$ trichloroacetic acid (Sigma-Aldrich; Merck KGaA; cat. no. 91228) at room temperature, washed with distilled $\mathrm{H}_{2} \mathrm{O}$ and air-dried. Cells were stained with $100 \mu \mathrm{l}$ of $0.4 \%$ SRB stain (Sigma-Aldrich; Merck KGaA; cat. no. S1402) (diluted in $1 \%$ acetic acid) for $30 \mathrm{~min}$ at room temperature, washed with acetic acid (Sigma-Aldrich; Merck KGaA; cat no. 33209) and air-dried. SRB stain was solubilized in $10 \mathrm{mM}$ unbuffered Tris base solution. Absorbance was measured at a wavelength of $540 \mathrm{~nm}$ with reference wavelength of $650 \mathrm{~nm}$ using a microplate reader. Cell proliferation was calculated according to the following formula: Cell proliferation $=100-[$ (absorbance of treated cells/absorbance of untreated cells) x100]. $\mathrm{IC}_{50}$ values were calculated using GraphPad Prism software version 5 (GraphPad Software, Inc.) to compare the cytotoxicity of the two complexes. For subsequent cell migration and invasion assays, the $\mathrm{IC}_{50}$ dose, one dose above the $\mathrm{IC}_{50}$ and one dose below the $\mathrm{IC}_{50}$ were used. For cell localization, mRNA and protein expression assays, cells were treated with the $\mathrm{IC}_{50}$ dose.

Cell migration by wound healing assay. MDA-MB-231 cells were seeded in 24-well plates and incubated at $37^{\circ} \mathrm{C}$ with $5 \%$ $\mathrm{CO}_{2}$ until they reach $80-90 \%$ confluence. A $100-\mu 1$ pipette tip was used to make a single scratch in the cell monolayer and image of the scratch was captured at $0 \mathrm{~h}$ with a light microscope (magnification, $\mathrm{x} 4$ ). Subsequently, cells were treated with various concentrations of curcumin, $\mathrm{B}(\mathrm{Cur})_{2}$ and $\mathrm{Fe}(\mathrm{Cur})_{3}$ or vehicle (control group) and incubated for $24 \mathrm{~h}$ at $37^{\circ} \mathrm{C}$ with $5 \% \mathrm{CO}_{2}$. The concentrations used were 5, 10, 15, 20, 25 and $30 \mu \mathrm{M}$ for curcumin and $\mathrm{B}(\mathrm{Cur})_{2}$, and $2,4,5,6$ and $8 \mu \mathrm{M}$ for $\mathrm{Fe}(\mathrm{Cur})_{3}$. On day 2, the width of the scratch was photographed and measured. Wound closure was calculated according to the following formula: Wound closure $=100$-[(scratch width at $24 \mathrm{~h} / \mathrm{scratch}$ width at $0 \mathrm{~h}$ ) x100]. Cells were not serum-starved during the assay.

Agarose invasion assay. The under-agarose assay was performed to determine the random invasion of treated and untreated cells towards serum components found in the agarose gel. Ultra-pure agarose $(0.9 \%$; Invitrogen; Thermo Fisher Scientific, Inc.) was dissolved in PBS supplemented with minimum essential medium (Gibco; Thermo Fisher Scientific, Inc.) containing 5\% FBS and incubated at room temperature in 6-well plates until it solidifies. Subsequently, 2-mm wells were formed in the agarose gel as previously described (60) and cells ( $4 \times 10^{4}$ cells/well) were pre-treated with 5, 10, 15, 20, 25 and $30 \mu \mathrm{M}$ curcumin and $\mathrm{B}(\mathrm{Cur})_{2}$ and 2, 4, 5, 6 and $8 \mu \mathrm{M}$ $\mathrm{Fe}(\mathrm{Cur})_{3}$ (or vehicle for control) before being loaded into the wells. Following $24 \mathrm{~h}$ incubation, the number of cells that had invaded the agarose gel were manually counted under a light microscope (magnification, $\mathrm{x} 4$ ).

Profiling of apoptosis-associated proteins. The effect of curcumin, $\mathrm{B}(\mathrm{Cur})_{2}$ and $\mathrm{Fe}(\mathrm{Cur})_{3}$ on the expression of apoptosis-associated proteins was determined using the Proteome Profiler ${ }^{\mathrm{TM}}$ Array Human Apoptosis Array kit (R\&D Systems, Inc.; cat no. ARY009) according to the manufacturer's instructions. Briefly, MDA-MB-231 cells were cultured in a $75 \mathrm{~cm}^{2}$ flask and treated for $48 \mathrm{~h}$ with curcumin $(25 \mu \mathrm{M}), \mathrm{B}(\mathrm{Cur})_{2}$ $(35 \mu \mathrm{M}), \mathrm{Fe}(\mathrm{Cur})_{3}(8 \mu \mathrm{M})$ or vehicle. Cells $(80 \%$ confluent $)$ were lysed and total proteins of treated and untreated cells were extracted and quantified using a Bradford Assay Protein Quantitation kit (Abcam). Extraction was performed using the solution provided in the kit 'Lysis Buffer 17' (Part no. 895943). 
The extraction solution contained aprotinin $(10 \mu \mathrm{g} / \mathrm{ml})$, leupeptin $(10 \mu \mathrm{g} / \mathrm{ml})$ and pepstatin $(10 \mu \mathrm{g} / \mathrm{ml})$. Protein arrays (nitrocellulose membranes spotted with 35 apoptotic proteins) were blocked with the array buffer 1 for $1 \mathrm{~h}$ at room temperature. Subsequently, proteins ( $280 \mu \mathrm{g}$ ) were transferred onto the arrays and incubated overnight at $4^{\circ} \mathrm{C}$. After being washed, the arrays were incubated at room temperature with antibody detection cocktail for $1 \mathrm{~h}$ followed by the addition of Streptavidin-HRP for $30 \mathrm{~min}$. The signal was finally obtained by adding Chemi Reagent Mix on the membrane. Protein spots were visualized using LI-COR detection system and the pixel density of each spot was quantified using Image $\mathbf{J}$ software (National Institutes of Health, version 1.46r). The relative expression of proteins in the treated cells were normalized to those in the untreated cells. The relative changes were based on differences in the pixel density of each spot displayed on images of the membrane array. The assay was performed in duplicate and the mean of the pixel density value was used for calculations.

RNA extraction. Total RNA was extracted from MDA-MB-231 cells following treatment with curcumin, $\mathrm{B}(\mathrm{Cur})_{2}, \mathrm{Fe}(\mathrm{Cur})_{3}$ or vehicle by using the RNeasy kit (Qiagen; cat. no. 74104) according to the manufacturer's protocol. The concentration of RNA was determined using a NanoDrop 1,000 spectrophotometer (Thermo Fisher Scientific, Inc.).

Ion-channel gene expression analysis by reverse transcription-quantitative (RT-q) PCR. Total RNA $(1 \mu \mathrm{g})$ from cells treated with curcumin, $\mathrm{B}(\mathrm{Cur})_{2}, \mathrm{Fe}(\mathrm{Cur})_{3}$ or vehicle was reverse transcribed into cDNA using the $\mathrm{RT}^{2}$ First Strand kit (Qiagen; cat. no. 330401) according to the manufacturers' protocol. cDNA was then subjected to RT-qPCR array analysis for a panel of 84 neuronal ion channel genes. RT-qPCR was performed on a 96-well Human Neuronal Ion Channels $\mathrm{RT}^{2}$ profiler PCR array (cat. no. PAHS-036ZA; Qiagen) using $\mathrm{RT}^{2}$ SYBR Green/ROX PCR Master Mix (Qiagen) and an ABI 7500 real time PCR machine (Applied Biosystems; Thermo Fisher Scientific, Inc.) according to the manufacturer's protocol. The reaction conditions were as follows: $10 \mathrm{~min}$ at $95^{\circ} \mathrm{C}$ followed by 40 cycles of $15 \mathrm{sec}$ at $95^{\circ} \mathrm{C}$ and $1 \mathrm{~min}$ at $60^{\circ} \mathrm{C}$. Each sample was run in biological triplicates. The gene expression data were uploaded and analyzed using an online analysis software package (Qiagen, Inc., processed via the Qiagen portal at http://www.qiagen. com/geneglobe, July 2018). The array included five housekeeping genes as internal standards for data normalization, ACTB, B2M, GAPDH, HPRT1 and RPLP0. Relative gene expression was represented by fold change which was calculated by $\mathrm{RT}^{2}$-analysis software using the threshold cycle $(\mathrm{Ct})$ and based upon the $2^{-\Delta \Delta \mathrm{Ct}}$ method (61). Fold change was defined by the normalised gene expression $\left(2^{-\Delta \mathrm{Cr}}\right)$ in the Test Sample divided by the normalized gene expression $\left(2^{-\Delta \mathrm{C} t}\right)$ in the Control Sample (vehicle).

Statistical analysis. Data were presented as the means \pm standard error of the mean of at least three independent experiments. Statistical analyses were performed using SPSS version 25 (IBM Corp.) and GraphPad Prism version
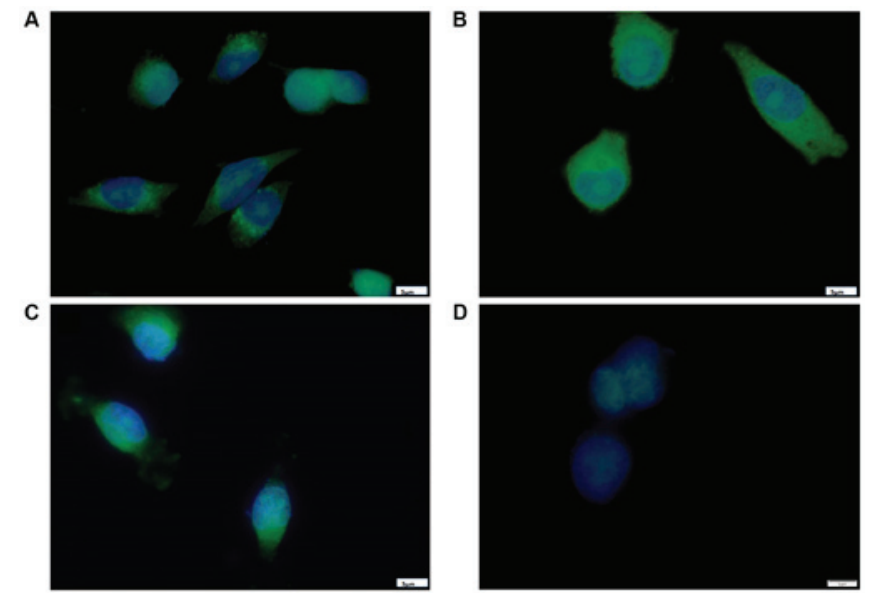

Figure 2. Localization of (A) curcumin, (B) $\mathrm{B}(\mathrm{Cur})_{2}$, (C) $\mathrm{Fe}(\mathrm{Cur})_{3}$ and (D) DMSO vehicle in MDA-MB-231 cells. Cells were seeded at subconfluency and left to attach overnight at $37^{\circ} \mathrm{C}$ with $5 \% \mathrm{CO}_{2}$. The following day, cells were treated with $\mathrm{IC}_{50}$ doses of curcumin, $\mathrm{B}(\mathrm{Cur})_{2}$ or $\mathrm{Fe}(\mathrm{Cur})_{3}$ (green) for $5 \mathrm{~min}$ and subsequently fixed. Cells were counterstained with DAPI as a nuclear stain (blue). Magnification, x100. Scale bar, $5 \mu \mathrm{m}$. B(Cur) ${ }_{2}$, boron-curcumin; $\mathrm{Fe}(\mathrm{Cur})_{3}$, iron-curcumin.

5 (GraphPad Software, Inc.). Data were compared using Student's t-test and two-way ANOVA followed by Tukey's post hoc test. $\mathrm{P}<0.05$ was considered to indicate a statistically significant difference.

\section{Results}

Curcumin, $\mathrm{B}(\mathrm{Cur})_{2}$ and $\mathrm{Fe}(\mathrm{Cur})_{3}$ localize in the cell cytoplasm and around the nucleus. The results from fluorescence microscopy displayed a cytoplasmic localization of curcumin $\mathrm{B}(\mathrm{Cur})_{2}$ and $\mathrm{Fe}(\mathrm{Cur})_{3}$ in MDA-MB-231 cells (Fig. 2); however, the three compounds displayed differences in their exact localization after a short incubation period. As presented in Fig. 2A, the curcumin-treated cells displayed fluorescence mainly around the perinuclear region with a punctate pattern. In Fig. 2B, cells incubated with $\mathrm{B}(\mathrm{Cur})_{2}$ displayed homogenous fluorescence in the cytoplasm, and a few cells displayed a distinct halo around the nucleus, presumably within the nuclear membrane. As presented in Fig. $2 \mathrm{C}, \mathrm{Fe}(\mathrm{Cur})_{3}$-treated cells displayed a nuclear-centric pattern of localization with no obvious fluorescence in the nuclear membrane or nucleus. Furthermore, the three compounds altered the morphology of MDA-MB-231 cells from the typical spindle-shape to a more spherical shape.

Curcumin, $B(\mathrm{Cur})_{2}$ and $\mathrm{Fe}(\mathrm{Cur})_{3}$ are cytotoxicfor $\mathrm{MDA}-\mathrm{MB}-231$ cells. The effect of various concentrations $(5-100 \mu \mathrm{M})$ of curcumin, $\mathrm{B}(\mathrm{Cur})_{2}$ and $\mathrm{Fe}(\mathrm{Cur})_{3}$ on cell proliferation was assessed using the SRB assay. The results demonstrated that curcumin displayed an inhibitory effect on MDA-MB-231 cell proliferation of $66-85 \%$, with an effective dose starting at $30 \mu \mathrm{M}$ curcumin (Fig. $3 \mathrm{~A}$ ). By contrast, $\mathrm{B}(\mathrm{Cur})_{2}$ displayed a weaker cytotoxic effect (60\%) on MDA-MB-231 cells, which occurred with a higher dose $(40 \mu \mathrm{M} \text {; Fig. 3B). Fe(Cur })_{3}$ displayed the most potent cytotoxic effect on MDA-MB-231 cell proliferation (20-90\%), with a significant decrease in cell proliferation at the lowest dose ( $5 \mu \mathrm{M}$; Fig. 3C). In addition, the 
A

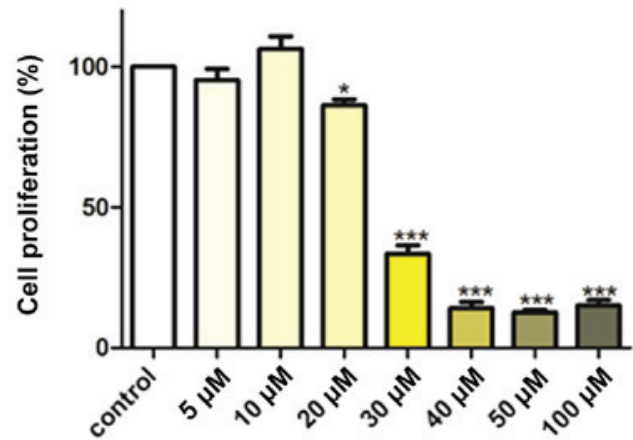

B

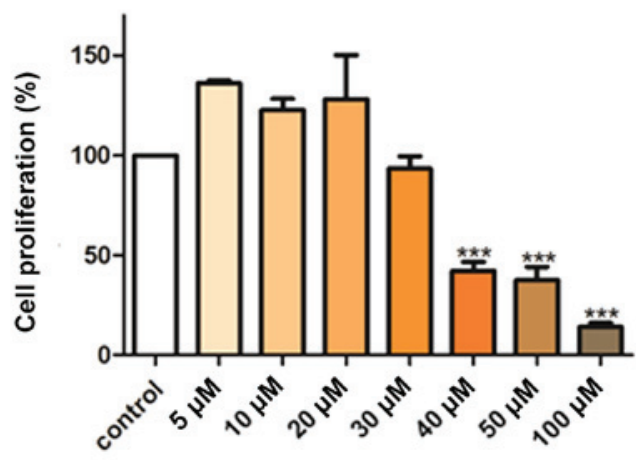

C

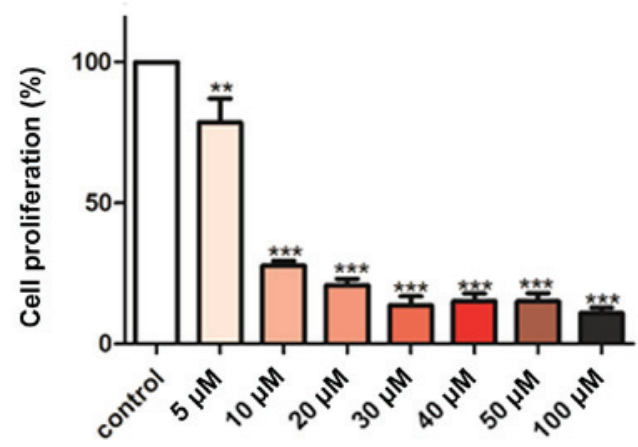

Figure 3. Effect of (A) curcumin, (B) $\mathrm{B}(\mathrm{Cur})_{2}$ and (C) $\mathrm{Fe}(\mathrm{Cur})_{3}$ on MDA-MB-231 cell proliferation. Cells grown in 96-well plates were untreated (control; white bars) or treated with curcumin, $\mathrm{B}(\mathrm{Cur})_{2}$ or $\mathrm{Fe}(\mathrm{Cur})_{3}$ for $48 \mathrm{~h}$ $(5-100 \mu \mathrm{M})$. Cell proliferation was assessed using the Sulforhodamine B assay. Data were presented as the means \pm standard error of the mean of 5-6 independent experiments. ${ }^{*} \mathrm{P}<0.05,{ }^{* *} \mathrm{P}<0.01$ and ${ }^{* * * *} \mathrm{P}<0.001$ vs. control. $\mathrm{B}(\mathrm{Cur})_{2}$, boron-curcumin; $\mathrm{Fe}(\mathrm{Cur})_{3}$, iron-curcumin.

$\mathrm{IC}_{50}$ values of curcumin, $\mathrm{B}(\mathrm{Cur})_{2}$ and $\mathrm{Fe}(\mathrm{Cur})_{3}$ were 25,35 and $8 \mu \mathrm{M}$, respectively.

Curcumin and $\mathrm{B}(\mathrm{Cur})_{2}$ alter $\mathrm{MDA}-\mathrm{MB}-231$ cell migratory ability. The results from the wound healing assay demonstrated that curcumin and $\mathrm{B}(\mathrm{Cur})_{2}$ had an inhibitory effect on MDA-MB-231 cell migratory ability (Fig. 4A). Curcumin and $\mathrm{B}(\mathrm{Cur})_{2}$ inhibited cell migration by $60-70 \%$ at $20-30 \mu \mathrm{M}$ and 15-35 $\mu \mathrm{M}$, respectively (Fig. 4B and C). $\mathrm{Fe}(\mathrm{Cur})_{3}$ had no effect on cell migratory ability (Fig. 4C).

Curcumin, $\mathrm{B}(\mathrm{Cur})_{2}$ and $\mathrm{Fe}(\mathrm{Cur})_{3}$ inhibit MDA-MB-231 cell random invasion. Curcumin, $\mathrm{B}(\mathrm{Cur})_{2}$ and $\mathrm{Fe}(\mathrm{Cur})_{3}$ significantly inhibited cell invasion (Fig. 5). Curcumin was the most effective, inhibiting cell invasion by $16-84 \%$ at concentrations between 5 and $30 \mu \mathrm{M}$ (Fig. $5 \mathrm{~A}) . \mathrm{B}(\mathrm{Cur})_{2}$ and $\mathrm{Fe}(\mathrm{Cur})_{3}$ inhibited cell invasion by $45-56$ and $48-53 \%$, respectively (Fig. 5B and C).
Effects of curcumin, $\mathrm{B}(\mathrm{Cur})_{2}$ and $\mathrm{Fe}(\mathrm{Cur})_{3}$ on apoptosisassociated proteins. The relative expression levels of 35 apoptosis-related proteins were assessed. A total of 17 proteins were detected in the MDA-MB-231 cell extracts according to the proteome profiler assay (Table I). The relative expression of the proapoptotic proteins cytochrome $\mathrm{c}$ and cleaved caspase-3 was markedly increased in MDA-MB-231 cells following treatment with $\mathrm{B}(\mathrm{Cur})_{2}$ and $\mathrm{Fe}(\mathrm{Cur})_{3}$. Cell treatment with curcumin also increased the expression of cytochrome $\mathrm{c}$ and cleaved caspase-3, but in a more modest way. Furthermore, cell treatment with curcumin, $\mathrm{B}(\mathrm{Cur})_{2}$ and $\mathrm{Fe}(\mathrm{Cur})_{3}$ decreased the expression of the three antiapoptotic proteins cIAP-1, claspin and survivin by $<10$-fold. In addition, an increase in the expression of haem oxygenase-1 (HO-1) was observed in MDA-MB-231 cells following treatment with curcumin, $\mathrm{B}(\mathrm{Cur})_{2}$ and $\mathrm{Fe}(\mathrm{Cur})_{3}$, in particular with $\mathrm{B}(\mathrm{Cur})_{2}$ and $\mathrm{Fe}(\mathrm{Cur})_{3}$ higher compared with curcumin.

Ion channel gene expression. The relative expression of 84 ion-channel genes was analysed using the ion channel array profiler. The relative expression levels of 26 ion-channel genes were statistically significantly different in cells treated with curcumin, $\mathrm{B}(\mathrm{Cur})_{2}$ or $\mathrm{Fe}(\mathrm{Cur})_{3}$ compared with the untreated control cells. Furthermore, MDA-MB-231 cells treated with curcumin, $\mathrm{B}(\mathrm{Cur})_{2}$ and $\mathrm{Fe}(\mathrm{Cur})_{3}$ displayed expression levels $>10$-fold higher for 16 ion channel genes, including seven potassium channels and nine non-potassium channels, compared with the untreated control cells (vehicle; Fig. 6A and B). The expression levels of $\mathrm{K} v 2.1$ and $\mathrm{K} v 3.2$ were increased by $>50$-fold in MDA-MB-cells treated with curcumin, $\mathrm{B}(\mathrm{Cur})_{2}$ or $\mathrm{Fe}(\mathrm{Cur})_{3}$. Furthermore, cells treated with $\mathrm{B}(\mathrm{Cur})_{2}$ displayed a 50 -fold increase in $\mathrm{K} v 4.2$ expression level compared with the control cells. In addition, the relative expression levels of bestrophin-1 (BEST1) and calcium voltage-gated channel auxiliary subunit $\gamma 4$ (CACNG4) were increased by $>50$-fold in cells treated with $\mathrm{Fe}(\mathrm{Cur})_{3}$ compared with control cells.

\section{Discussion}

The present study demonstrated that curcumin, $\mathrm{B}(\mathrm{Cur})_{2}$ and $\mathrm{Fe}(\mathrm{Cur})_{3}$ may be cytotoxic for MDA-MB-231 cells. In addition to inhibiting cell proliferation, the three compounds inhibited cell invasive ability; however, only curcumin and $\mathrm{B}(\mathrm{Cur})_{2}$ reduced cell migratory ability.

As $\mathrm{B}(\mathrm{Cur})_{2}$ and $\mathrm{Fe}(\mathrm{Cur})_{3}$ are new compounds, their effect on breast cancer cells requires further investigation. It has been reported that curcumin localized primarily in the perinuclear region of the cell (62). Despite structural differences, $\mathrm{B}(\mathrm{Cur})_{2}$ and $\mathrm{Fe}(\mathrm{Cur})_{3}$ displayed a similar pattern of cellular localization to curcumin in the present study. Kunwar et al (63) reported that curcumin localization was mainly at the plasma membrane, followed by the cytoplasm and the nucleus in MCF-7 breast cancer cells (63). Cytoplasmic localization of iron-containing curcumin derivative has also been reported in MCF-7 breast cancer cells (64). In the present study, curcumin, $\mathrm{B}(\mathrm{Cur})_{2}$ and $\mathrm{Fe}(\mathrm{Cur})_{3}$ induced morphological changes in MDA-MB-231 cells from a typical spindle shape to a rounded structure with no visible blebs near the plasma membrane. Ganguly et al (65) also described this feature, suggesting that curcumin may modify 
A
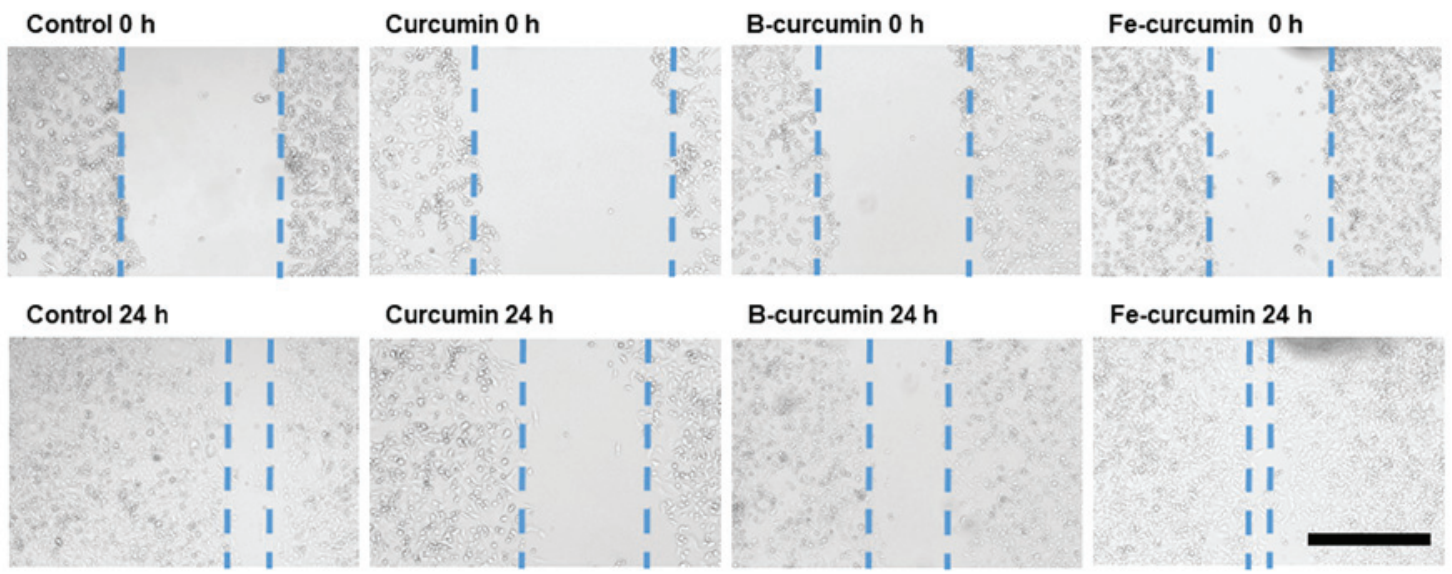

Curcumin $24 \mathrm{~h}$

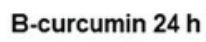

Fe-curcumin $24 \mathrm{~h}$
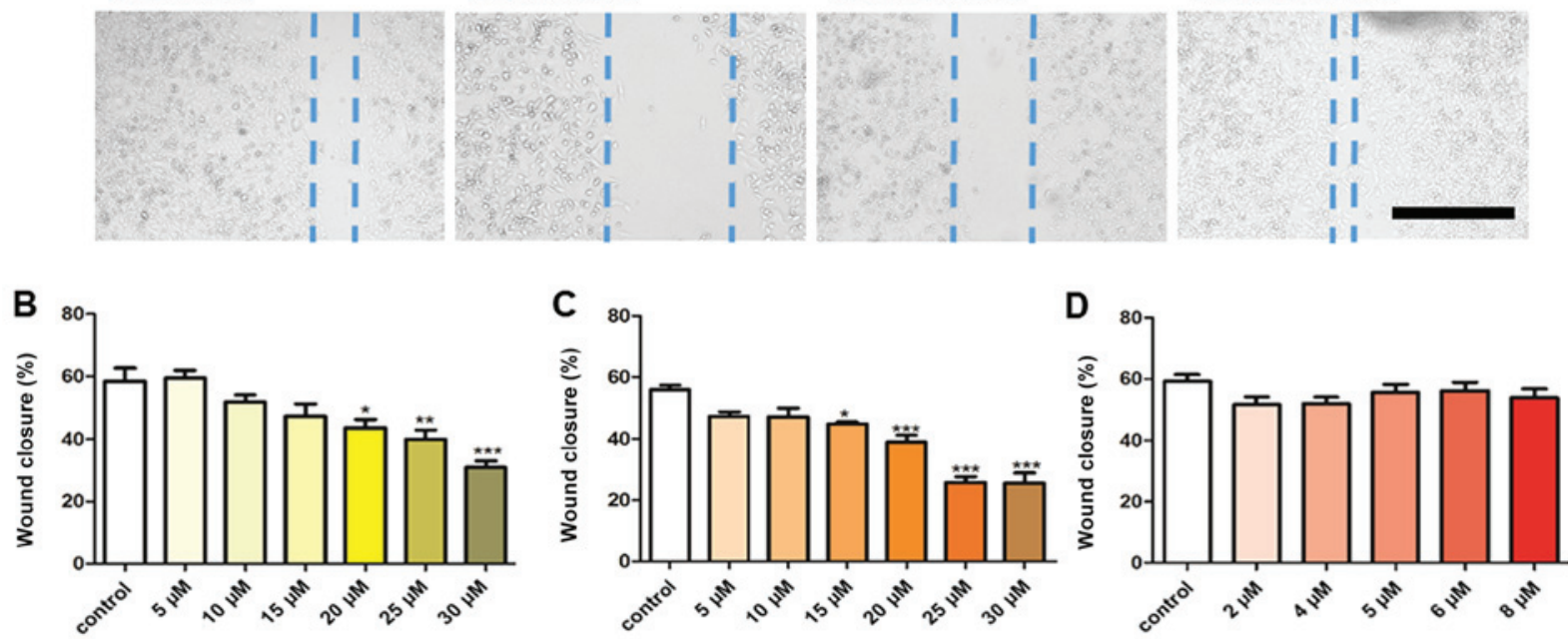

Figure 4. Effect of curcumin and curcumin complexes on MDA-MB-231 wound healing capacity. (A) Representative images of wound healing following exposure to the three compounds at 0 and $24 \mathrm{~h}$. Magnification, $\mathrm{x} 4$. Scale bar, $500 \mu \mathrm{m}$. Curcumin and $\mathrm{B}(\mathrm{Cur})_{2}$ were tested at $30 \mu \mathrm{M}$ and $\mathrm{Fe}(\mathrm{Cur})_{3}$ was tested at $8 \mu \mathrm{M}$. Effects of (B) curcumin, (C) $\mathrm{B}(\mathrm{Cur})_{2}$ and (D) $\mathrm{Fe}(\mathrm{Cur})_{3}$ on MDA-MB-231 cell migration. Cells grown in 24-well plates were untreated (control; white bars) or treated with different concentrations of curcumin, $\mathrm{B}(\mathrm{Cur})_{2}$ or $\mathrm{Fe}(\mathrm{Cur})_{3}$ for $24 \mathrm{~h}$. Cell migration was assessed using a wound healing assay. Data were presented as the means \pm standard error of the mean of $4-9$ independent experiments. ${ }^{*} \mathrm{P}<0.05,{ }^{* *} \mathrm{P}<0.01$ and ${ }^{* * *} \mathrm{P}<0.001$ vs. control. $\mathrm{B}(\mathrm{Cur})_{2}$, boron-curcumin; $\mathrm{Fe}(\mathrm{Cur})_{3}$, iron-curcumin.

the cell shape and reduce cell attachment by downregulating focal adhesion kinase expression.

To further investigate the cell death mechanism, reverse transcription-quantitative PCR was performed to assess the expression of ion channels, and apoptosis proteome profiling was also conducted. The expression levels of the proapoptotic proteins cleaved caspase 3 and cytochrome c were increased in cells treated with curcumin, $\mathrm{B}(\mathrm{Cur})_{2}$ or $\mathrm{Fe}(\mathrm{Cur})_{3}$. The mitochondrial release of cytochrome $\mathrm{c}$ induces the activation of the caspase cascade associated with the intrinsic pathway of apoptosis (66). The increased expression of cytochrome $\mathrm{c}$ and cleaved caspase- 3 reported in the present study suggested that the intrinsic pathway of apoptosis was associated with curcumin exposure in MDA-MB-231 cells. Furthermore, phosphorylated p53 expression levels were slightly decreased following treatment with $\mathrm{B}(\mathrm{Cur})_{2}$ and $\mathrm{Fe}(\mathrm{Cur})_{3}$. Chiu and $\mathrm{Su}(14,40)$ reported similar effect of curcumin on MDA-MB-231 cells, and suggested that curcumin may induce apoptosis via a p53 independent pathway or a p53-dependent Bax pathway.

In the present study, HO-1 expression level was increased in MDA-MB-231 cells in response to treatment with curcumin, $\mathrm{B}(\mathrm{Cur})_{2}$ and $\mathrm{Fe}(\mathrm{Cur})_{3}$. Previous studies also reported that curcumin treatment induces HO-1 overexpression in vitro and in vivo (67-71). In hepatoma epithelial cells, the induction of HO-1 expression occurs via a mechanism involving increased oxidative stress and p38 activation (72), whereas in renal epithelial cells, the mechanism involves activation of the protein-1 activator transcription factor (73). Although the protein expression of the antiapoptotic and proproliferative
HO-1 was induced by curcumin in the present study, previous studies indicated that curcumin displays anticancer effects. It has been reported that high HO-1 expression favours cancer cell proliferation, poor prognosis and resistance to therapy (74-82). Furthermore, it was demonstrated that HO-1 is associated with antiapoptotic $(83,84)$, proangiogenic $(85)$ and prometastatic (86) activities. HO-1 also promotes cancer cell proliferation via a mechanism that is independent of its catalytic activity, the HO-1 nuclear translocation-induced alterations of gene transcription $(87,88)$. At present, HO-1 is considered as a potential therapeutic target for various cancers $(74,89)$. However, an increase in HO-1 enzyme activity has also been reported to display anticancer effects $(90,91)$, including via the promotion of apoptosis $(92,93)$. Furthermore, it was reported that HO-1 overexpression in breast cancer cell lines can inhibit cell proliferation and invasive ability and induce apoptosis (94-96). Similarly, Lee et al $(48,69)$ demonstrated that curcumin can induce HO-1 protein overexpression in MDA-MB-231 cells, leading to decreased cell proliferation and invasive ability.

In the present study, curcumin, $\mathrm{B}(\mathrm{Cur})_{2}$ and $\mathrm{Fe}(\mathrm{Cur})_{3}$ had variable effects on the expression of certain ion channel genes. High gene expression levels were observed for the Kv2.1, $\mathrm{K} v 3.2$ and $\mathrm{K} v 4.2$ potassium channels following treatment with curcumin, $\mathrm{B}(\mathrm{Cur})_{2}$ or $\mathrm{Fe}(\mathrm{Cur})_{3}$. Furthermore, high expression levels of CACNG4, which is a calcium channel coding gene, and BEST1, which is a calcium-activated chloride channel coding gene, were observed in MDA-MB-231 cells following treatment with curcumin, $\mathrm{B}(\mathrm{Cur})_{2}$ and $\mathrm{Fe}(\mathrm{Cur})_{3}$. 

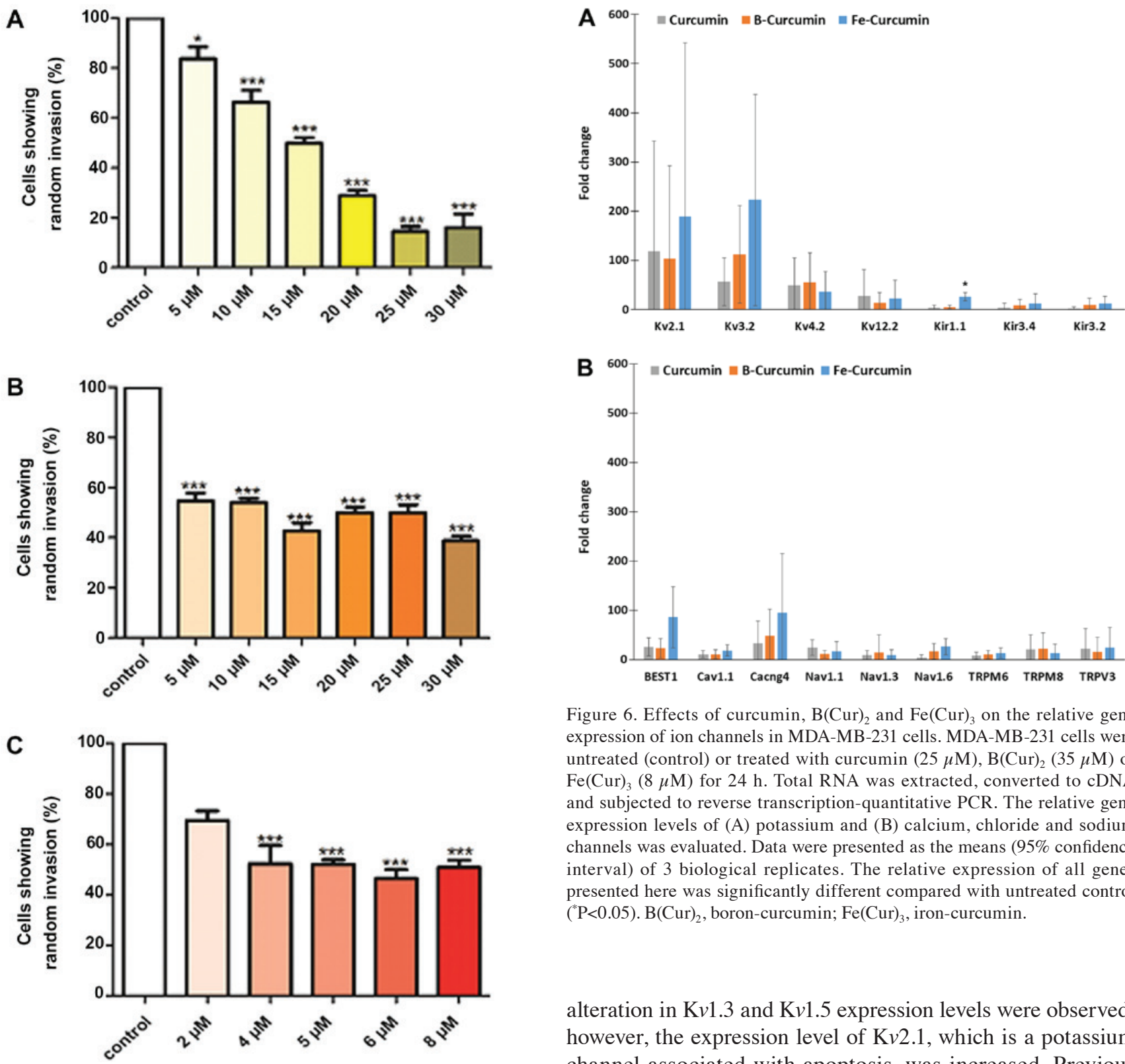

Figure 5. Effect of (A) curcumin, (B) $\mathrm{B}(\mathrm{Cur})_{2}$ and (C) $\mathrm{Fe}(\mathrm{Cur})_{3}$ on the random invasion of MDA-MB-231 cells towards serum components found in agarose gel. Cells loaded in agarose wells were untreated (control; open bars), or treated with different concentrations of curcumin, $\mathrm{B}(\mathrm{Cur})_{2}$ or $\mathrm{Fe}(\mathrm{Cur})_{3}$ for $24 \mathrm{~h}$. Curcumin and $\mathrm{B}(\mathrm{Cur})_{2}$ were tested at 5-30 $\mu \mathrm{M}$ and $\mathrm{Fe}(\mathrm{Cur})_{3}$ was tested at 2-8 $\mu \mathrm{M}$. Invading cells were manually counted. Data were presented as the means \pm standard error of the mean of 3-9 independent experiments. ${ }^{*} \mathrm{P}<0.05$ and ${ }^{* * *} \mathrm{P}<0.001$ vs. control. $\mathrm{B}(\mathrm{Cur})_{2}$, boron-curcumin; $\mathrm{Fe}(\mathrm{Cur})_{3}$, iron-curcumin.

Ion channel overexpression may result in a proapoptotic and antiproliferative response by increasing the movement of ions that favours a decrease in cell volume, which may be involved in initiating apoptosis $(43-45,48-51)$. The cellular potassium efflux induces AVD and subsequent apoptotic events. By downregulating potassium channel expression, cancer cells can therefore evade apoptosis $(44,53,97)$. Numerous voltage-gated potassium channels are known to influence AVD in cancer cells, including Kv1.1, Kv1.3, Kv1.5, $\mathrm{K} v 2.1$ and $\mathrm{K} v 11.1$ (53), with several studies focusing on $\mathrm{K} v 1.3$ and $\mathrm{K} v 1.5(51,52,54,98-101)$. In the present study, no significant

Figure 6. Effects of curcumin, $\mathrm{B}(\mathrm{Cur})_{2}$ and $\mathrm{Fe}(\mathrm{Cur})_{3}$ on the relative gene expression of ion channels in MDA-MB-231 cells. MDA-MB-231 cells were untreated (control) or treated with curcumin $(25 \mu \mathrm{M}), \mathrm{B}(\mathrm{Cur})_{2}(35 \mu \mathrm{M})$ or $\mathrm{Fe}(\mathrm{Cur})_{3}(8 \mu \mathrm{M})$ for $24 \mathrm{~h}$. Total RNA was extracted, converted to cDNA and subjected to reverse transcription-quantitative PCR. The relative gene expression levels of (A) potassium and (B) calcium, chloride and sodium channels was evaluated. Data were presented as the means $(95 \%$ confidence interval) of 3 biological replicates. The relative expression of all genes presented here was significantly different compared with untreated control $\left({ }^{*} \mathrm{P}<0.05\right)$. $\mathrm{B}(\mathrm{Cur})_{2}$, boron-curcumin; $\mathrm{Fe}(\mathrm{Cur})_{3}$, iron-curcumin.

alteration in $\mathrm{K} v 1.3$ and $\mathrm{K} v 1.5$ expression levels were observed; however, the expression level of $\mathrm{K} v 2.1$, which is a potassium channel associated with apoptosis, was increased. Previous studies reported that neuronal apoptosis requires a potassium efflux via the Kv2.1 channel $(97,102)$. Curcumin has also been reported to reduce $\mathrm{K} v 2.1$ potassium currents by modulating the inactivation gating of this channel (57). Kv2.1 overexpression, which was observed in the present study, may be a cellular response to the inhibition of the function of this voltage-gates potassium channel.

Cancer cell survival is partly attributed to the evasion of apoptotic processes (39). In the present study, the results from the proteome profile and ion channel expression analyses identified two potential mechanisms underlying cancer cell apoptosis evasion. The findings suggested that curcumin may increase the expression level of $\mathrm{HO}-1$ and $\mathrm{K} v 2.1$ and that $\mathrm{HO}-1$ may counterbalance the effects of $\mathrm{K} v 2.1$. HO- 1 catalyses the breakdown of haem to generate biliverdin, iron and carbon monoxide (CO), which inhibit apoptosis. Subsequently, HO-1 and its products may display some antiapoptotic effects in certain cells. $\mathrm{CO}$ inhibits the potassium currents generated by the proapoptotic $\mathrm{K} v 2.1$ channel $(49,50,103,104)$. The increase in $\mathrm{K} v 2.1$ expression level observed in the present study may be a cellular response to the HO-1-mediated inhibition of the 
Table I. Regulation of pro-apoptotic and anti-apoptotic proteins in MDA-MB-231 cell line following treatment with curcumin, $\mathrm{B}(\mathrm{Cur})_{2}$ and $\mathrm{Fe}(\mathrm{Cur})_{3}$.

\begin{tabular}{|c|c|c|c|c|}
\hline Protein & Effect on apoptosis & Curcumin & $\mathrm{B}(\mathrm{Cur})_{2}$ & $\mathrm{Fe}(\mathrm{Cur})_{3}$ \\
\hline $\mathrm{Bad}$ & Pro & $\downarrow$ & & $\downarrow$ \\
\hline Pro-caspase 3 & Pro & $\downarrow$ & $\downarrow$ & $\downarrow$ \\
\hline Cleaved caspase 3 & Pro & $\downarrow$ & $\uparrow \uparrow \uparrow$ & $\uparrow \uparrow \uparrow$ \\
\hline Cytochrome c & Pro & $\downarrow$ & $\uparrow \uparrow$ & $\uparrow \uparrow$ \\
\hline TRAIL R2/DR5 & Pro & $\downarrow$ & & $\downarrow$ \\
\hline FADD & Pro & $\downarrow$ & $\downarrow$ & $\downarrow$ \\
\hline HIF- $1 \alpha$ & Pro & $\downarrow$ & & \\
\hline HSP70 & Pro & $\downarrow$ & $\downarrow$ & $\downarrow$ \\
\hline HTRA2/Omi & Pro & $\downarrow$ & $\downarrow$ & $\downarrow$ \\
\hline Phospho-p53 (S15) & Pro & $\downarrow$ & $\downarrow$ & $\downarrow$ \\
\hline Phospho-p53 (S46) & Pro & $\downarrow$ & $\downarrow$ & $\downarrow$ \\
\hline Phospho-p53 (S392) & Pro & $\downarrow$ & $\downarrow$ & $\downarrow$ \\
\hline SMAC/Diablo & Pro & $\downarrow$ & & $\downarrow$ \\
\hline cIAP-1 & Anti & $\downarrow$ & $\downarrow$ & $\downarrow$ \\
\hline Claspin & Anti & $\downarrow$ & $\downarrow$ & $\downarrow$ \\
\hline HO-1 & Anti & $\uparrow \uparrow \uparrow \uparrow$ & $\uparrow \uparrow \uparrow \uparrow \uparrow$ & $\uparrow \uparrow \uparrow \uparrow \uparrow$ \\
\hline Survivin & Anti & $\downarrow$ & $\downarrow$ & $\downarrow$ \\
\hline
\end{tabular}

Direction of arrow indicates up- or downregulation compared with untreated control group. Number of arrows indicates the relative difference in density of pixels between control and treated sample. The fold difference in pixel density was as follows: $\uparrow \uparrow=10, \uparrow \uparrow \uparrow=100, \uparrow \uparrow \uparrow \uparrow=1,000$ and $\uparrow \uparrow \uparrow \uparrow \uparrow=10,000$. B $(\mathrm{Cur})_{2}$, boron-curcumin; $\mathrm{Fe}(\mathrm{Cur})_{3}$, iron-curcumin.

$\mathrm{K} v 2.1$ channel activity. However, the association between HO-1 and $\mathrm{K} v 2.1$ in breast cancer cells requires further investigation.

Conversely with $\mathrm{K} v 2.1$, only a few studies reported an association between $\mathrm{K} v 3.2$ and apoptosis. Lan et al (105) reported high relative expression of $\mathrm{K} v 1.3, \mathrm{~K} v 1.5, \mathrm{~K} v 1.6, \mathrm{~K} v 2.1$ and $\mathrm{K} v 2.2$ in numerous gastric cancer cell lines; however, Kv3.2 expression level was only just detectable. The increased expression level of $\mathrm{K} v 3.2$ observed in the present study may therefore be specific to breast cancer cells. Some K $v$ channels are considered oxygen sensors, and Song et al (106) demonstrated that $\mathrm{K} v 3.1$ and $\mathrm{K} v 3.4$ are tumour hypoxia-related channels involved in cancer cell migratory and invasive abilities. Kv3.1 and $\mathrm{K} v 3.4$ protein expression in A549 and MDA-MB-231 cells increase in a cell density-dependent manner. When $\mathrm{K} v 3.1$ and $\mathrm{K} v 3.4$ were inhibited using a Kv3 subfamily-specific blocker, both cell migration and invasion were inhibited (106). In the present study, cell treatment with $\mathrm{Fe}(\mathrm{Cur})_{3}$ induced the largest increase in $\mathrm{K} v 3.2$ expression; however, $\mathrm{Fe}(\mathrm{Cur})_{3}$ was the only compound that failed to inhibit the breast cancer cell migratory ability in the present study. The overexpression of Kv3.2 may be linked to an attenuation in MDA-MB-231 cell ability to migrate.

In the present study, BEST1 was the only anion channel that was significantly upregulated in response to curcumin treatment. BEST1 is responsible for the production of an outward flow of chloride ions, which counterbalances transient membrane potentials induced by potassium efflux for cellular electroneutrality $(51,107)$. Several family members of the calcium-activated chloride channels, including BEST1, have been reported to promote cell proliferation and tumorigenesis $(52,53,108,109)$. Furthermore, it was reported that both potassium voltage-gated channel subfamily $\mathrm{H}$ member 1 and BEST1 are involved in the transformation of slow-growing $\mathrm{T}_{84}$ colonic carcinoma cells into fast-growing $\mathrm{T}_{84}$ cells (109).

In the present study, the effects of curcumin, $\mathrm{B}(\mathrm{Cur})_{2}$ and $\mathrm{Fe}(\mathrm{Cur})_{3}$ were evaluated in one breast cancer cell line only. Although the MDA-MB-231 cell line (36), has proven useful in laboratory investigations of genetics, molecular biology and biology of TNBC (37), this represents a limitation to this study. Further investigation in additional breast cancer cell lines, including MCF-7, is therefore required. Both MCF-7 and MDA-MB-231 cell lines are invasive ductal/breast carcinoma cells; however, these cells display significant phenotypic and genotypic differences. MCF-7 is a hormone dependent cell line due to its expression of ER and PR, whereas the MDA-MB-231 cell line lacks ER and PR. Since MDA-MB-231 cells are highly metastatic and more aggressive compared with MCF-7 cells, the MDA-MB-231 cell line was the most appropriate cell line for investigating the anticancer properties of curcumin compounds in the present study.

Previous studies reported that $\mathrm{B}(\mathrm{Cur})_{2}$ and $\mathrm{Fe}(\mathrm{Cur})_{3}$ display improved photostability and high fluorescence efficiency compared with curcumin $(9,10,34,35)$. The present study investigated whether curcumin complexes possessed similar biological properties as curcumin. The results demonstrated that $\mathrm{Fe}(\mathrm{Cur})_{3}$ was more effective at inhibiting cell proliferation and random invasion at low doses compared with curcumin. Conversely, $\mathrm{B}(\mathrm{Cur})_{2}$ was only effective at inhibiting the cell migratory ability. $\mathrm{B}(\mathrm{Cur})_{2}$ and $\mathrm{Fe}(\mathrm{Cur})_{3}$ displayed similar anticancer properties to curcumin. Curcumin may serve as an adjuvant for 
chemotherapy. The increase in $\mathrm{K} v 2.1, \mathrm{~K} v 3.2$ and HO-1 highlight important changes in molecular responses to curcumin induced inhibition of proliferation and invasion of breast cancer cells. In conclusion, the present study demonstrated that HO-1 and potassium channels may be considered as important therapeutic targets in breast cancer.

\section{Acknowledgements}

Not applicable.

\section{Funding}

This study was supported by the RCSI (Bahrain) internal research grants (grant no. BR00061) and the Dr Ali Al-Khalifa Research Fund (Bahrain) (grant no. AK-2017).

\section{Availability of data and material}

The datasets used and/or analysed during the current study are available from the corresponding author on reasonable request.

\section{Authors' contributions}

FM designed the study, performed cell and molecular experiments and analysed data. FR had the original research idea, developed the experimental design, conducted data analysis and reading and revised the manuscript. ST performed cell and molecular experiments and analysed data. SC synthesised the curcumin complexes. SF was responsible for funding acquisition, data curation and manuscript writing. All authors read and approved the final manuscript.

\section{Ethics approval and consent to participate}

Not applicable.

\section{Patient consent for publication}

Not applicable.

\section{Competing interests}

The authors declare that they have no competing interests.

\section{References}

1. Bray F, Ferlay J, Soerjomataram I, Siegel RL, Torre LA and Jemal A: Global cancer statistics 2018: GLOBOCAN estimates of incidence and mortality worldwide for 36 cancers in 185 countries. CA Cancer J Clin 68: 394-424, 2018.

2. Blows FM, Driver KE, Schmidt MK, Broeks A, van Leeuwen FE, Wesseling J, Cheang MC, Gelmon K, Nielsen TO, Blomqvist C, et al: Subtyping of breast cancer by immunohistochemistry to investigate a relationship between subtype and short and long term survival: A collaborative analysis of data for 10,159 cases from 12 studies. PLoS Med 7: e1000279, 2010.

3. Hugh J, Hanson J, Cheang MC, Nielsen TO, Perou CM, Dumontet C, Reed J, Krajewska M, Treilleux I, Rupin M, et al Breast cancer subtypes and response to docetaxel in node-positive breast cancer: Use of an immunohistochemical definition in the BCIRG 001 trial. J Clin Oncol 27: 1168-1176, 2009.
4. Nielsen TO, Hsu FD, Jensen K, Cheang M, Karaca G, Hu Z, Hernandez-Boussard T, Livasy C, Cowan D, Dressler L, et al: Immunohistochemical and clinical characterization of the basal-like subtype of invasive breast carcinoma. Clin Cancer Res 10: 5367-5374, 2004.

5. Carey LA, Dees EC, Sawyer L, Gatti L, Moore DT, Collichio F, Ollila DW, Sartor CI, Graham ML and Perou CM: The triple negative paradox: Primary tumor chemosensitivity of breast cancer subtypes. Clin Cancer Res 13: 2329-2334, 2007.

6. Dent R, Trudeau M, Pritchard KI, Hanna WM, Kahn HK, Sawka CA, Lickley LA, Rawlinson E, Sun P and Narod SA: Triple-negative breast cancer: Clinical features and patterns of recurrence. Clin Cancer Res 13: 4429-4434, 2007.

7. Li X, Yang J, Peng L, Sahin AA, Huo L, Ward KC, O'Regan R, Torres MA and Meisel JL: Triple-negative breast cancer has worse overall survival and cause-specific survival than non-triple-negative breast cancer. Breast Cancer Res Treat 161: 279-287, 2017.

8. Liedtke C, Mazouni C, Hess KR, André F, Tordai A, Mejia JA, Symmans WF, Gonzalez-Angulo AM, Hennessy B, Green M, et al: Response to neoadjuvant therapy and long-term survival in patients with triple-negative breast cancer. J Clin Oncol 26: 1275-1281, 2008.

9. Massat NJ, Dibden A, Parmar D, Cuzick J, Sasieni PD and Duffy SW: Impact of screening on breast cancer mortality: The UK program 20 years on. Cancer Epidemiol Biomarkers Prev 25: 455-462, 2016

10. Kalager M, Zelen M, Langmark F and Adami HO: Effect of screening mammography on breast-cancer mortality in Norway. N Engl J Med 363: 1203-1210, 2010.

11. Gonzalez-Angulo AM, Morales-Vasquez F and Hortobagyi GN: Overview of resistance to systemic therapy in patients with breast cancer. Adv Exp Med Biol 608: 1-22, 2007.

12. Choudhuri T, Pal S, Das T and Sa G: Curcumin selectively induces apoptosis in deregulated cyclin D1-expressed cells at $\mathrm{G} 2$ phase of cell cycle in a p53-dependent manner. J Biol Chem 280: 20059-20068, 2005

13. Pal S, Bhattacharyya S, Choudhuri T, Datta GK, Das T and Sa G: Amelioration of immune cell number depletion and potentiation of depressed detoxification system of tumor-bearing mice by curcumin. Cancer Detect Prev 29: 470-478, 2005.

14. Shim JS, Kim JH, Cho HY, Yum YN, Kim SH, Park HJ, Shim BS, Choi SH and Kwon HJ: Irreversible inhibition of CD13/aminopeptidase $\mathrm{N}$ by the antiangiogenic agent curcumin. Chem Biol 10: 695-704, 2003.

15. Yang X, Thomas DP, Zhang X, Culver BW, Alexander BM, Murdoch WJ, Rao MN, Tulis DA, Ren J and Sreejayan N: Curcumin inhibits platelet-derived growth factor-stimulated vascular smooth muscle cell function and injury-induced neointima formation. Arterioscler Thromb Vasc Biol 26: 85-90, 2006.

16. Zeitlin P: Can curcumin cure cystic fibrosis? N Engl J Med 351: 606-608, 2004

17. Carroll RE, Benya RV, Turgeon DK, Vareed S, Neuman M, Rodriguez L, Kakarala M, Carpenter PM, McLaren C, Meyskens FL Jr and Brenner DE: Phase IIa clinical trial of curcumin for the prevention of colorectal neoplasia. Cancer Prev Res (Phila) 4: 354-364, 2011.

18. He ZY, Shi CB, Wen H, Li FL, Wang BL and Wang J: Upregulation of $\mathrm{p} 53$ expression in patients with colorectal cancer by administration of curcumin. Cancer Invest 29: 208-213, 2011.

19. Hejazi J, Rastmanesh R, Taleban FA, Molana SH, Hejazi E, Ehtejab $\mathrm{G}$ and Hara N: Effect of curcumin supplementation during radiotherapy on oxidative status of patients with prostate cancer: A double blinded, randomized, placebo-controlled study. Nutr Cancer 68: 77-85, 2016.

20. Epstein J, Sanderson IR and Macdonald TT: Curcumin as a therapeutic agent: The evidence from in vitro, animal and human studies. Br J Nutr 103: 1545-1557, 2010.

21. Durgaprasad S, Pai CG, Vasanthkumar, Alvres JF and Namitha S: A pilot study of the antioxidant effect of curcumin in tropical pancreatitis. Indian J Med Res 122: 315-318, 2005.

22. Sahin Kavakl1 H, Koca C and Alıcı O: Antioxidant effects of curcumin in spinal cord injury in rats. Ulus Travma Acil Cerrahi Derg 17: 14-18, 2011

23. Meng B, Li J and Cao H: Antioxidant and antiinflammatory activities of curcumin on diabetes mellitus and its complications. Curr Pharm Des 19: 2101-2113, 2013.

24. Lüer S, Troller R and Aebi C: Antibacterial and antiinflammatory kinetics of curcumin as a potential antimucositis agent in cancer patients. Nutr Cancer 64: 975-981, 2012. 
25. Beevers CS and Huang S: Pharmacological and clinical properties of curcumin. Botanics Targets Ther 1: 5-18, 2011.

26. Shishodia S, Sethi G and Aggarwal BB: Curcumin: Getting back to the roots. Ann N Y Acad Sci 1056: 206-217, 2005.

27. Aggarwal BB, Kumar A and Bharti AC: Anticancer potential of curcumin: Preclinical and clinical studies. Anticancer Res 23 363-398, 2003

28. Tønnesen HH, Karlsen J and van Henegouwen GB: Studies on curcumin and curcuminoids. VIII. Photochemical stability of curcumin. Z Lebensm Unters Forsch 183: 116-122, 1986.

29. Wang YJ, Pan MH, Cheng AL, Lin LI, Ho YS, Hsieh CY and Lin JK: Stability of curcumin in buffer solutions and characterization of its degradation products. J Pharm Biomed Anal 15: $1867-1876,1997$.

30. Cartiera MS, Ferreira EC, Caputo C, Egan ME, Caplan MJ and Saltzman WM: Partial correction of cystic fibrosis defects with PLGA nanoparticles encapsulating curcumin. Mol Pharm 7: 86-93, 2010.

31. Liang G, Shao L, Wang Y, Zhao C, Chu Y, Xiao J, Zhao Y, Li X and Yang S: Exploration and synthesis of curcumin analogues with improved structural stability both in vitro and in vivo as cytotoxic agents. Bioorg Med Chem 17: 2623-2631, 2009.

32. Wanninger S, Lorenz V, Subhan A and Edelmann FT: Metal complexes of curcumin-synthetic strategies, structures and medicinal applications. Chem Soc Rev 44: 4986-5002, 2015.

33. Greish K, Pittalà V, Taurin S, Taha S, Bahman F, Mathur A Jasim A, Mohammed F, El-Deeb IM, Fredericks S and Rashid-Doubell F: Curcumin-copper complex nanoparticles for the management of triple-negative breast cancer. Nanomaterials (Basel) 8: pii: E884, 2018.

34. Mohammed F, Rashid-Doubell F, Cassidy S and Henari F: A comparative study of the spectral, fluorometric properties and photostability of natural curcumin, iron- and boron-complexed curcumin. Spectrochim Acta A Mol Biomol Spectrosc 183: 439-450, 2017

35. Pröhl M, Schubert US, Weigand W and Gottschaldt M: Metal complexes of curcumin and curcumin derivatives for molecular imaging and anticancer therapy. Coord Chem Rev 307: 32-41, 2016.

36. Cailleau R, Olivé M and Cruciger QV: Long-term human breast carcinoma cell lines of metastatic origin: Preliminary characterization. In Vitro 14: 911-915, 1978.

37. Chavez KJ, Garimella SV and Lipkowitz S: Triple negative breast cancer cell lines: One tool in the search for better treatment of triple negative breast cancer. Breast Dis 32: 35-48, 2010.

38. Osborne CK: Tamoxifen in the treatment of breast cancer. N Engl J Med 339: 1609-1618, 1998.

39. Hanahan D and Weinberg RA: Hallmarks of cancer: The next generation. Cell 144: 646-674, 2011.

40. Chiu TL and Su CC: Curcumin inhibits proliferation and migration by increasing the $\mathrm{Bax}$ to $\mathrm{Bcl}-2$ ratio and decreasing NF-kappaBp65 expression in breast cancer MDA-MB-231 cells. Int J Mol Med 23: 469-475, 2009.

41. Lv ZD, Liu XP, Zhao WJ, Dong Q, Li FN, Wang HB and Kong B: Curcumin induces apoptosis in breast cancer cells and inhibits tumor growth in vitro and in vivo. Int J Clin Exp Pathol 7: $2818-2824,2014$

42. Kim HI, Huang H, Cheepala S, Huang S and Chung J: Curcumin inhibition of integrin (alpha6beta4)-dependent breast cancer cell motility and invasion. Cancer Prev Res (Phila) 1: 385-391, 2008.

43. Yee NS: Roles of TRPM8 Ion channels in cancer: Proliferation, survival, and invasion. Cancers (Basel) 7: 2134-2146, 2015.

44. Pardo LA and Stühmer W: The roles of $\mathrm{K}(+)$ channels in cancer. Nat Rev Cancer 14: 39-48, 2014.

45. Urrego D, Tomczak AP, Zahed F, Stühmer W and Pardo LA Potassium channels in cell cycle and cell proliferation. Philos Trans R Soc Lond B Biol Sci 369: 20130094, 2014.

46. Litan A and Langhans SA: Cancer as a channelopathy: Ion channels and pumps in tumor development and progression. Front Cell Neurosci 9: 86, 2015

47. Djamgoz MB and Onkal R: Persistent current blockers of voltage-gated sodium channels: A clinical opportunity for controlling metastatic disease. Recent Pat Anticancer Drug Discov 8: 66-84, 2013.

48. Wang Y, Yang Z, Meng Z, Cao H, Zhu G, Liu T and Wang X: Knockdown of TRPM8 suppresses cancer malignancy and enhances epirubicin-induced apoptosis in human osteosarcoma cells. Int J Biol Sci 10: 90-102, 2013.

49. Hoffmann EK and Lambert IH: Ion channels and transporters in the development of drug resistance in cancer cells. Philos Trans R Soc Lond B Biol Sci 369: 20130109, 2014.
50. Yang $\mathrm{M}$ and Brackenbury WJ: Membrane potential and cancer progression. Front Physiol 4: 185, 2013.

51. Bortner CD and Cidlowski JA: Ion channels and apoptosis in cancer. Philos Trans R Soc Lond B Biol Sci 369: 20130104, 2014

52. Felipe A, Bielanska J, Comes N, Vallejo A, Roig S, Ramón Y Cajal S, Condom E, Hernández-Losa J and Ferreres JC: Targeting the voltage-dependent $\mathrm{K}(+)$ channels Kv1.3 and Kv1.5 as tumor biomarkers for cancer detection and prevention. Curr Med Chem 19: 661-674, 2012.

53. Szabò I, Zoratti M and Gulbins E: Contribution of voltage-gated potassium channels to the regulation of apoptosis. FEBS Lett 584: 2049-2056, 2010.

54. Szabó I, Bock J, Grassmé H, Soddemann M, Wilker B, Lang F, Zoratti $\mathrm{M}$ and Gulbins E: Mitochondrial potassium channe Kv1.3 mediates Bax-induced apoptosis in lymphocytes. Proc Natl Acad Sci USA 105: 14861-14866, 2008.

55. Banderali U, Belke D, Singh A, Jayanthan A, Giles WR and Narendran A: Curcumin blocks Kv11.1 (erg) potassium current and slows proliferation in the infant acute monocytic leukemia cell line THP-1. Cell Physiol Biochem 28: 1169-1180, 2011.

56. Lian YT, Yang XF, Wang ZH, Yang Y, Yang Y, Shu YW, Cheng LX and Liu K: Curcumin serves as a human kv1.3 blocker to inhibit effector memory T lymphocyte activities. Phytother Res 27: 1321-1327, 2013

57. Aréchiga-Figueroa IA, Delgado-Ramirez M, Morán-Zendejas R and Rodriguez-Menchaca AA: Modulation of Kv2.1 channels inactivation by curcumin. Pharmacol Rep 67: 1273-1279, 2015.

58. Khalil MI, AL-Zahem AM and Qunaibit MM: Synthesis, characterization, and antitumor activity of binuclear curcumin-metal(II) hydroxo complexes. Med Chem Res 23: 1683-1689, 2014.

59. Skehan P, Storeng R, Scudiero D, Monks A, McMahon J, Vistica D, Warren JT, Bokesch H, Kenney S and Boyd MR: New colorimetric cytotoxicity assay for anticancer-drug screening. J Natl Cancer Inst 82: 1107-1112, 1990.

60. Heit B and Kubes P: Measuring chemotaxis and chemokinesis: The under-agarose cell migration assay. Sci STKE 2003: PL5, 2003.

61. Livak KJ and Schmittgen TD: Analysis of relative gene expression data using real-time quantitative PCR and the 2(-Delta Delta C(T)) method. Methods 25: 402-408, 2001

62. Hope-Roberts M and Horobin RW: A review of curcumin as a biological stain and as a self-visualizing pharmaceutical agent. Biotech Histochem 92: 315-323, 2017.

63. Kunwar A, Barik A, Mishra B, Rathinasamy K, Pandey R and Priyadarsini KI: Quantitative cellular uptake, localization and cytotoxicity of curcumin in normal and tumor cells. Biochim Biophys Acta 1780: 673-679, 2008.

64. Sarkar T, Butcher RJ, Banerjee S, Mukherjee S and Hussain A: Visible light-induced cytotoxicity of a dinuclear iron(III) complex of curcumin with low-micromolar IC50 value in cancer cells. Inorganica Chimica Acta 439: 8-17, 2016.

65. Ganguly KK, Sen T, Pal S, Biswas J and Chatterjee A: Studies on focal adhesion kinase in human breast cancer cell MDA-MB-231. Adv Biol Chem 2: 29-42, 2012.

66. Garrido C, Galluzzi L, Brunet M, Puig PE, Didelot C and Kroemer G: Mechanisms of cytochrome c release from mitochondria. Cell Death Differ 13: 1423-1433, 2006.

67. Xiao Y, Xia J, Wu S, Lv Z, Huang S, Huang H, Su X, Cheng J and Ke Y: Curcumin inhibits acute vascular inflammation through the activation of heme oxygenase-1. Oxid Med Cell Longev 2018: 3295807, 2018.

68. Wu SY, Lee YR, Huang CC, Li YZ, Chang YS, Yang CY, Wu JD and Liu YW: Curcumin-induced heme oxygenase-1 expression plays a negative role for its anti-cancer effect in bladder cancers. Food Chem Toxicol 50: 3530-3536, 2012.

69. Lee WY, Chen YC, Shih CM, Lin CM, Cheng CH, Chen KC and Lin CW: The induction of heme oxygenase-1 suppresses heat shock protein 90 and the proliferation of human breast cancer cells through its byproduct carbon monoxide. Toxicol Appl Pharmacol 274: 55-62, 2014.

70. Park $\mathrm{J}$ and Conteas $\mathrm{CN}$ : Anti-carcinogenic properties of curcumin on colorectal cancer. World J Gastrointest Oncol 2: $169-175,2010$.

71. Balogun E, Hoque M, Gong P, Killeen E, Green CJ, Foresti R, Alam $J$ and Motterlini R: Curcumin activates the haem oxygenase-1 gene via regulation of $\mathrm{Nrf} 2$ and the antioxidant-responsive element. Biochem J 371: 887-895, 2003.

72. McNally SJ, Harrison EM, Ross JA, Garden OJ and Wigmore SJ: Curcumin induces heme oxygenase 1 through generation of reactive oxygen species, p38 activation and phosphatase inhibition. Int J Mol Med 19: 165-172, 2007. 
73. Mimche PN, Taramelli D and Vivas L: The plant-based immunomodulator curcumin as a potential candidate for the development of an adjunctive therapy for cerebral malaria. Malar J 10 (Suppl 1): S10, 2011.

74. Nitti M, Piras S, Marinari UM, Moretta L, Pronzato MA and Furfaro AL: HO-1 induction in cancer progression: A matter of cell adaptation. Antioxidants (Basel) 6: pii: E29, 2017.

75. Jeon WK, Hong HY, Seo WC, Lim KH, Lee HY, Kim WJ, Song SY and Kim BC: Smad7 sensitizes A549 lung cancer cells to cisplatin-induced apoptosis through heme oxygenase-1 inhibition. Biochem Biophys Res Commun 420: 288-292, 2012.

76. Kongpetch S, Kukongviriyapan V, Prawan A, Senggunprai L, Kukongviriyapan U and Buranrat B: Crucial role of heme oxygenase-1 on the sensitivity of cholangiocarcinoma cells to chemotherapeutic agents. PLoS One 7: e34994, 2012

77. Lv X, Song DM, Niu YH and Wang BS: Inhibition of heme oxygenase-1 enhances the chemosensitivity of laryngeal squamous cell cancer Hep-2 cells to cisplatin. Apoptosis 21: 489-501, 2016.

78. Tracey N, Creedon H, Kemp AJ, Culley J, Muir M, Klinowska T and Brunton VG: HO-1 drives autophagy as a mechanism of resistance against HER2-targeted therapies. Breast Cancer Res Treat 179: 543-555, 2020.

79. Zhao Z, Xu Y, Lu J, Xue J and Liu P: High expression of HO-1 predicts poor prognosis of ovarian cancer patients and promotes proliferation and aggressiveness of ovarian cancer cells. Clin Transl Oncol 20: 491-499, 2018.

80. Becker JC, Fukui H, Imai Y, Sekikawa A, Kimura T, Yamagishi H, Yoshitake N, Pohle T, Domschke W and Fujimori T: Colonic expression of heme oxygenase-1 is associated with a better long-term survival in patients with colorectal cancer. Scand J Gastroenterol 42: 852-858, 2007.

81. Loboda A, Jozkowicz A and Dulak J: HO-1/CO system in tumor growth, angiogenesis and metabolism-targeting $\mathrm{HO}-1$ as an anti-tumor therapy. Vascul Pharmacol 74: 11-22, 2015.

82. Maines MD and Abrahamsson PA: Expression of heme oxygenase-1 (HSP32) in human prostate: Normal, hyperplastic, and tumor tissue distribution. Urology 47: 727-733, 1996.

83. Busserolles J, Megías J, Terencio MC and Alcaraz MJ: Heme oxygenase- 1 inhibits apoptosis in Caco- 2 cells via activation of Akt pathway. Int J Biochem Cell Biol 38: 1510-1517, 2006.

84. Tanaka S, Akaike T, Fang J, Beppu T, Ogawa M, Tamura F, Miyamoto Y and Maeda H: Antiapoptotic effect of haem oxygenase-1 induced by nitric oxide in experimental solic tumour. Br J Cancer 88: 902-909, 2003.

85. Cherrington JM, Strawn LM and Shawver LK: New paradigms for the treatment of cancer: The role of anti-angiogenesis agents. Adv Cancer Res 79: 1-38, 2000

86. Price JT and Thompson EW: Mechanisms of tumour invasion and metastasis: Emerging targets for therapy. Expert Opin Ther Targets 6: 217-233, 2002 .

87. Lin Q, Weis S, Yang G, Weng YH, Helston R, Rish K, Smith A, Bordner J, Polte T, Gaunitz F and Dennery PA: Heme oxygenase-1 protein localizes to the nucleus and activates transcription factors important in oxidative stress. J Biol Chem 282 20621-20633, 2007.

88. Biswas C, Shah N, Muthu M, La P, Fernando AP, Sengupta S, Yang G and Dennery PA: Nuclear heme oxygenase-1 (HO-1) modulates subcellular distribution and activation of $\mathrm{Nrf} 2$, impacting metabolic and anti-oxidant defenses. J Biol Chem 289: 26882-26894, 2014

89. Was H, Dulak J and Jozkowicz A: Heme oxygenase-1 in tumor biology and therapy. Curr Drug Targets 11: 1551-1570, 2010

90. Duckers HJ, Boehm M, True AL, Yet SF, San H, Park JL, Clinton Webb R, Lee ME, Nabel GJ and Nabel EG: Heme oxygenase-1 protects against vascular constriction and proliferation. Nat Med 7: 693-698, 2001

91. Taillé C, Almolki A, Benhamed M, Zedda C, Mégret J, Berger P, Lesèche G, Fadel E, Yamaguchi T, Marthan R, et al: Heme oxygenase inhibits human airway smooth muscle proliferation via a bilirubin-dependent modulation of ERK1/2 phosphorylation. J Biol Chem 278: 27160-27168, 2003.

92. Ozawa N, Goda N, Makino N, Yamaguchi T, Yoshimura Y and Suematsu M: Leydig cell-derived heme oxygenase-1 regulates apoptosis of premeiotic germ cells in response to stress. J Clin Invest 109: 457-467, 2002
93. Liu XM, Chapman GB, Wang H and Durante W: Adenovirusmediated heme oxygenase-1 gene expression stimulates apoptosis in vascular smooth muscle cells. Circulation 105 79-84, 2002

94. Hill M, Pereira V, Chauveau C, Zagani R, Remy S, Tesson L, Mazal D, Ubillos L, Brion R, Asghar K, et al: Heme oxygenase-1 inhibits rat and human breast cancer cell proliferation: Mutua cross inhibition with indoleamine 2,3-dioxygenase. FASEB J 19: 1957-1968, 2005.

95. Lin CW, Shen SC, Hou WC, Yang LY and Chen YC: Heme oxygenase-1 inhibits breast cancer invasion via suppressing the expression of matrix metalloproteinase-9. Mol Cancer Ther 7: 1195-1206, 2008.

96. Andreadi CK, Howells LM, Atherfold PA and Manson MM Involvement of Nrf2, p38, B-Raf, and nuclear factor-kappaB, but not phosphatidylinositol 3-kinase, in induction of hemeoxygenase-1 by dietary polyphenols. Mol Pharmacol 69: 1033-1040, 2006.

97. Pal SK, Takimoto K, Aizenman E and Levitan ES: Apoptotic surface delivery of K+ channels. Cell Death Differ 13: 661-667, 2006.

98. Comes N, Bielanska J, Vallejo-Gracia A, Serrano-Albarrás A, Marruecos L, Gómez D, Soler C, Condom E, Ramón Y Cajal S, et al: The voltage-dependent $\mathrm{K}(+)$ channels Kv1.3 and Kv1.5 in human cancer. Front Physiol 4: 283, 2013.

99. Lowinus T, Heidel FH, Bose T, Nimmagadda SC, Schnöder T, Cammann C, Schmitz I, Seifert U, Fischer T, Schraven B and Bommhardt U: Memantine potentiates cytarabine-induced cell death of acute leukemia correlating with inhibition of Kv1.3 potassium channels, AKT and ERK1/2 signalin. Cell Commun Signal 17: 5, 2019

100. Teisseyre A, Palko-Labuz A, Sroda-Pomianek K and Michalak K: Voltage-gated potassium channel Kv1.3 as a target in therapy of cancer. Front Oncol 9: 933, 2019.

101. Wu J, Chen Z, Liu Q, Zeng W, Wu X and Lin B: Silencing of $\mathrm{Kv} 1.5$ gene inhibits proliferation and induces apoptosis of osteosarcoma cells. Int J Mol Sci 16: 26914-26926, 2015.

102. Pal S, Hartnett KA, Nerbonne JM, Levitan ES and Aizenman E: Mediation of neuronal apoptosis by Kv2.1-encoded potassium channels. J Neurosci 23: 4798-4802, 2003.

103. Al-Owais MM, Dallas ML, Boyle JP, Scragg JL and Peers C: Heme oxygenase-1 influences apoptosis via CO-mediated inhibition of K+ channels. Adv Exp Med Biol 860: 343-351, 2015.

104. Al-Owais MM, Scragg JL, Dallas ML, Boycott HE, Warburton P, Chakrabarty A, Boyle JP and Peers C: Carbon monoxide mediates the anti-apoptotic effects of heme oxygenase-1 in medulloblastoma DAOY cells via $\mathrm{K}+$ channel inhibition. J Biol Chem 287: 24754-24764, 2012.

105. Lan M, Shi Y, Han Z, Hao Z, Pan Y, Liu N, Guo C, Hong L, Wang J, Qiao T and Fan D: Expression of delayed rectifier potassium channels and their possible roles in proliferation of human gastric cancer cells. Cancer Biol Ther 4: 1342-1347, 2005.

106. Song MS, Park SM, Park JS, Byun JH, Jin HJ, Seo SH, Ryu PD and Lee SY: Kv3.1 and Kv3.4, are involved in cancer cell migration and invasion. Int J Mol Sci 19: pii: E1061, 2018.

107. Schwab A, Fabian A, Hanley PJ and Stock C: Role of ion channels and transporters in cell migration. Physiol Rev 92: 1865-1913, 2012.

108. Duvvuri U, Shiwarski DJ, Xiao D, Bertrand C, Huang X, Edinger RS, Rock JR, Harfe BD, Henson BJ, Kunzelmann K, et al: TMEM16A induces MAPK and contributes directly to tumorigenesis and cancer progression. Cancer Res 72: 3270-3281, 2012

109. Spitzner M, Martins JR, Soria RB, Ousingsawat J, Scheidt K, Schreiber R and Kunzelmann K: Eag1 and Bestrophin 1 are up-regulated in fast-growing colonic cancer cells. J Biol Chem 283: 7421-7428, 2008.

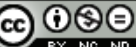

This work is licensed under a Creative Commons Attribution-NonCommercial-NoDerivatives 4.0 International (CC BY-NC-ND 4.0) License. 